\title{
The influence of stocking rate and male:female ratio on the production of breeding ostriches (Struthio camelus spp.) under commercial farming conditions
}

\author{
H. Lambrechts ${ }^{1,4}$, D. Swart ${ }^{2}$, S.W.P. Cloete ${ }^{3 \#}$, J.P.C. Greyling ${ }^{4}$ \\ and S.J. van Schalkwyk ${ }^{5}$ \\ ${ }^{1}$ Ostrich Research Division, Klein Karoo Agricultural Development Centre, PO Box 351, Oudtshoorn 6620, \\ South Africa \\ ${ }^{2}$ ARC-Range and Forage Institute (Grootfontein), PO Box X529, Middelburg, Eastern Cape, 5900 \\ ${ }^{3}$ Animal Production, Elsenburg Agricultural Development Centre, Private Bag X1, Elsenburg 7607 \\ ${ }^{4}$ Department of Animal, Wildlife \& Grassland Sciences, Free State University, PO Box 339, Bloemfontein 9300 \\ ${ }^{5}$ Mosstrich Group, PO Box 2629, Mossel Bay, 6500
}

\begin{abstract}
The study provides information on the reproductive performance of ostriches maintained at different stocking rates and male:female (M:F) ratios under intensive commercial conditions in the Little Karoo, South Africa. Breeding ostriches are concentrated on relatively small areas and through trampling have a most significant impact on the vegetation in the Little Karoo. Reproductive performance, as influenced by stocking rate and M:F ratio, was investigated. Stocking rates for the large flocks ranged from 114 to 210 birds/ha, and stocking rates for smaller flocks ranged between 9 to 13 birds in 0.13 ha and 0.30 ha camps, respectively. The different M:F ratios investigated, were $1 \mathrm{M}: 1 \mathrm{~F}$ (pairs), $1 \mathrm{M}: 2 \mathrm{~F}$ (trios) and $1 \mathrm{M}: 3 \mathrm{~F}$ (quads), for breeding systems maintained in 0.06 ha camps. In almost all breeding systems total and average egg production, fertility and hatchability were compromised when stocking rate was increased. High stocking rates were detrimental to the reproductive performance and reproductive behaviour of the flocks. Increasing the number of females per male had no negative influence on the reproduction traits, with a significantly higher production observed for breeding quads. Our findings indicated that ostrich breeding flocks can be maintained at stocking rates higher than those presently used on commercial ostrich farms. Breeding pairs, trios and quads can also be maintained on smaller areas, with acceptable production levels. Increasing stocking densities will have a possible inhibitory effect on the establishment of territories and use of space, thereby impacting on the reproductive behaviour of ostrich females and males in large flocks, respectively. This has important implications in terms of the intensification of ostrich farming especially in areas that are characterised by vegetation that is exposed to the trampling effect of ostriches.
\end{abstract}

Keywords: Ostriches, stocking density, male:female ratio, reproductive performance

${ }^{\#}$ Corresponding author. E-mail: schalkc@elsenburg.com

\section{Introduction}

Ostriches are the main farming enterprise in the Little Karoo region of South Africa and used to occur naturally in areas of the Little Karoo that are used mainly for agricultural purposes today. At present almost $65 \%$ of the South African ostrich breeding population is found in the Little Karoo region (Van Zyl, 2001). On commercial ostrich farms where the entire or part of the production cycle, i.e. breeding birds, artificial incubation and raising of chicks and slaughter birds is represented, ostriches can be concentrated on relatively small areas (South African Ostrich Business Chamber, 2003). The natural vegetation in the Little Karoo is of low nutritional quality and natural veld areas are most often used only as holding areas for breeding flocks, which are then fed commercial breeder diets. This practice differs from those employed by other livestock farming systems, e.g. sheep and beef cattle, where the natural veld areas serve as the main food source.

The maintenance of breeding ostriches in large flocks is a well-known practice in South Africa and Israel. In these countries breeding flocks can range in size from 50-100 birds and 150-200 birds, respectively (Deeming \& Bubier, 1999). Flocks are usually maintained in camps several hectares in size, with no clear guidelines on the optimal stocking rate for ostriches under free-range conditions. The male:female ratio (M:F) in South African breeding flocks is 5-6 males for every 10 females, which is similar to the 1M:2F ratio in Israel (Deeming \& Bubier, 1999). Guidelines of the South African Ostrich Business 
Chamber (2003) require a maximum camp size of 0.25 ha for a breeding pair or trio when birds are fed a concentrated breeding diet. In the case of larger breeding flocks the minimum stocking density is one breeding bird/10 ha for an 8-month breeding season. Breeding pairs, trios and quads are used as breeding systems in Australia, with the breeding quads consisting of two males and two females (More, 1997). In Poland ostriches are bred as pairs, trios or small flocks, and most farmers pay special attention to the space requirements of breeders to create optimum exercise conditions (Horbañczuk, 2002). According to the draft recommendations of the Standing Committee of the European Convention for the Protection of Animals Kept for Farming Purposes, the minimum space requirement for the maintenance of ratite breeding birds is $1200 \mathrm{~m}^{2}$, with larger areas recommended to ensure well-being and proper exercise conditions (Horbañczuk, 2002). However, no stocking density was recommended by Horbañczuk (2002).

According to the Code of Animal Welfare No. 21 of New Zealand (Animal Welfare Advisory Committee, 1998), the stocking rate for breeding pairs in open conditions should not exceed 20 birds/ha for breeding flocks. The minimum camp size required for breeding pairs and trios is 0.06 ha and 0.20 ha, respectively. No status in terms of percentage vegetation cover was mentioned in this document. Deeming \& Bubier (1999) stated that ostrich breeding enclosures can be small and be used to maintain breeding pairs and trios, but no recommendation is made of any dimensions for breeding camps. More (1997) also did not mention any dimensions for breeding enclosures.

The intensive nature of ostrich farming presents both the commercial farmer and the conservationist with a challenge to ensure that conservation of natural resources can co-exist with commercial ostrich farming. Scientific research on the production of ostriches in large commercial breeding systems is scarce, and this complicates the development of best practice techniques to enable producers to farm as costeffectively as possible (Adams \& Revell, 2003). Most of the available literature on the egg production performance of ostriches under intensive farming and wild conditions are compiled for breeding pairs, breeding trios and small flocks (Hurxthal, 1979; Jarvis et al., 1985; Foggin \& Van Niekerk, 1995; HicksAldredge, 1996; More, 1997; Deeming \& Bubier, 1999; Bunter \& Graser, 2000; Lambrechts et al., 2002). This study presents results on the reproductive performance of a large commercial breeding population and the influence of stocking rate and male:female ratio on reproductive traits.

\section{Materials and Methods}

Production data were obtained from an ostrich breeding flock of 4500 birds during two consecutive breeding seasons. The breeding colony was maintained as a single breeding operation near Ladismith, South Africa. The breeding colony consisted of birds maintained permanently on the farm and breeding birds translocated from another commercial breeding farm in the North-Western Province of South Africa. These birds were translocated to the Ladismith breeding farm approximately two months before the onset of the 2000/2001 breeding season.

During the 2000/2001 breeding season breeding birds maintained permanently on the Ladismith farm were allocated only to large breeding units, and the imported breeding birds were allocated to both large and small breeding units. The breeding birds were combined in July 2000 for a 7-month breeding season. At the end of August 2000, 40 females and 20 males were removed from each of four 210-bird flocks to establish two 120-bird and four 150-bird flocks. As a result of the shorter breeding season for the 120-bird and 150bird flocks, only the reproduction data recorded for all the breeding systems during the last five months of the $2000 / 2001$ breeding period were considered in the analysis.

Based on the results of the 210-bird flocks during the 2000/2001 breeding season, three breeding systems, i.e. 114-bird, 130-bird and 141-bird flocks were established in the second year of the study. The breeding quads and 210-birds flocks did not form part of the experimental groups in the 2001/2002 breeding season. Due to the allocation of a higher number of birds to large breeding flocks (results not presented here) that were maintained in approximately 40 to 70 ha camps, only 114 and 141 birds were allocated to the 120-bird and 150-bird breeding systems, respectively. The breeding birds were combined in July 2001 for a 7-month breeding period and results presented here represent data recorded for the entire 7-month breeding period. During both breeding seasons, the breeding birds received a complete balanced breeder diet at 2.5 $\mathrm{kg} / \mathrm{bird} /$ day and had free access to fresh, clean water.

Stocking rates and M:F ratios studied during the two consecutive breeding seasons are presented in Table 1. 
Table 1 Stocking rates and male:female (M:F) ratios of the commercial ostrich breeding operation maintained near Ladismith in the Western Cape, South Africa

\begin{tabular}{lccccc}
\hline Breeding system & $\begin{array}{c}\text { M:F ratio } \\
\text { (no. of females) }\end{array}$ & $\begin{array}{c}\text { Camp } \\
\text { size (ha) }\end{array}$ & $\begin{array}{c}\text { Camp size } \\
\left(\mathrm{m}^{2}\right)\end{array}$ & $\begin{array}{c}\text { Stocking density } \\
\left(\mathrm{m}^{2} / \mathrm{bird}\right)\end{array}$ & $\begin{array}{c}\text { Breeding season } \\
\text { studied }\end{array}$ \\
\hline Breeding pair & $1: 1(1)$ & 0.06 & 625 & 312.5 & $2000 / 2001$ \\
Breeding pair & $1: 1(1)$ & 0.13 & 1250 & 625.0 & $2001 / 2002$ \\
Breeding trio & $1: 2(2)$ & 0.06 & 625 & 208.3 & $2000 / 2001$ \\
Breeding trio & $1: 2(2)$ & 0.13 & 1250 & 416.7 & $2001 / 2002$ \\
Breeding quad & $1: 3(3)$ & 0.06 & 625 & 156.3 & $2000 / 2001$ \\
9-bird flock & $1: 2(6)$ & 0.13 & 1250 & 138.9 & $2000 / 2001$ \\
9-bird flock & $1: 2(6)$ & 0.30 & 3000 & 333.3 & $2001 / 2002$ \\
13-bird flock & $1: 1.2(9)$ & 0.35 & 3500 & 233.3 & $2000 / 2001$ \\
114 bird flock & $1: 2(76)$ & 1 & 10000 & 87.7 & $2001 / 2002$ \\
120-bird flock & $1: 2(80)$ & 1 & 10000 & 83.3 & $2000 / 2001$ \\
130-bird flock & $1: 2(86)$ & 1 & 10000 & 76.9 & $2001 / 2002$ \\
141-bird flock & $1: 2(94)$ & 1 & 10000 & 70.9 & $2001 / 2002$ \\
150-bird flock & $1: 2(100)$ & 1 & 10000 & 66.7 & $2000 / 2001$ \\
210-bird flock & $1: 2(140)$ & 1 & 10000 & 47.6 & $2000 / 2001$ \\
\hline
\end{tabular}

Eggs were collected daily and identified by means of camp number and date of production. Production was recorded individually for each breeding system. After collection, eggs were cleaned by dry wiping and disinfected by fumigation (80 g potassium permanganate in $130 \mathrm{~mL} 40 \%$ formaldehyde solution $/ \mathrm{m}^{2}$ for $20 \mathrm{~min}$; Smith et al., 1995). All eggs not suitable for incubation were noted for each breeding system and removed from storage. Reasons for rejection included broken/cracked eggshells, chalky eggshells and loose air cells (i.e. where the air cell was damaged during transport to the incubation facilities).

Eggs were stored upright with the air cell in the uppermost position. They were stored for a maximum of 10 days at $17-18{ }^{\circ} \mathrm{C}$ and $75 \%$ relative humidity, and were turned once daily through an angle of $45^{\circ}$. Eggs were artificially incubated in Buckeye ${ }^{\circledR}$ electronic incubators for a period of 38 days and candled on day 14 to establish early embryonic deaths and fertility, and on day 38 to establish late embryonic deaths. After hatch, chicks were kept in the hatcher for $24 \mathrm{~h}$ to allow sufficient time for the navel to close before being dispatched to contract growers. The number of unhatched eggs and reasons for not hatching during incubation were recorded throughout the study.

Definitions for reproduction traits are as follows:

Total egg production: total number of eggs produced per breeding system during the production period;

Average EP/female: average number of eggs produced per female during the production period;

Chicks (number): number of day-old chicks hatched;

Fertility (\%): [(Total eggs incubated - number of infertile eggs)/total eggs incubated] x 100;

Hatchability (\%): [(Total eggs incubated-total eggs rejected during incubation)/total eggs incubated] $\mathrm{x}$ 100.

The influence of stocking rate and male:female ratio was assessed by one-way analysis of variance procedures. In cases where trends were expected and where degrees of freedom for treatments exceeded one, the degrees of freedom for the number of birds were partitioned in orthogonal polynomials depicting linear tendencies. The LSMLMW computer programme (Harvey, 1990) was used for this purpose. When more than two means were compared, least significant differences were computed, providing that the comparisons were protected by a significant F-value in the ANOVA table (Snedecor \& Cochran, 1967). When only two means were compared, differences between means were tested for significance by using the t-test derived from the ANOVA table (Snedecor \& Cochran, 1967). 


\section{Results}

The 210-bird flocks had on average a higher total egg production during the 2000/2001 breeding season than the 150-bird and 120-bird flocks (Table 2). Although the F-value for treatment (flock size) in the analysis of variance table did not reach statistical significance $(\mathrm{P}=0.13)$, there was a suggestion of a linear increase $(\mathrm{P} \leq 0.05)$ in total egg production per camp with an increase in flock size. Fertility and hatchability declined $(\mathrm{P} \leq 0.05)$ with an increase in stocking rate. Linear regression coefficients amounted to $-0.062 \pm 0.020 \%$ per bird $\left(\mathrm{R}^{2}=0.987\right)$ for fertility and $-0.106 \pm 0.028 \%$ per bird $\left(\mathrm{R}^{2}=0.963\right)$ for hatchability. Average egg production was independent of stocking rate.

Table 2 The influence of stocking rate on the reproduction traits (means \pm s.e.) of ostriches maintained in 1 ha camps during the 2000/2001 breeding season

\begin{tabular}{lccc}
\hline & \multicolumn{3}{c}{ Size of breeding flock (1male:2 females) } \\
\cline { 2 - 4 } Parameter & 120 birds & 150 birds & 210 birds \\
\hline Number of replicates & 2 & 4 & 8 \\
Total egg production & $1748 \pm 515^{\mathrm{a}}$ & $2181 \pm 364^{\mathrm{a}}$ & $2859 \pm 257^{\mathrm{a}}$ \\
Chicks (number) & $515 \pm 176.2^{\mathrm{a}}$ & $707 \pm 124.6^{\mathrm{a}}$ & $844 \pm 88.1^{\mathrm{a}}$ \\
Average EP/female & $20.0 \pm 4.1^{\mathrm{a}}$ & $22.9 \pm 2.9^{\mathrm{a}}$ & $21.0 \pm 2.0^{\mathrm{a}}$ \\
Fertility (\%) & $85.8 \pm 1.9^{\mathrm{a}}$ & $83.2 \pm 1.4^{\mathrm{a}}$ & $79.9 \pm 1.0^{\mathrm{b}}$ \\
Hatchability (\%) & $70.1 \pm 2.6^{\mathrm{a}}$ & $64.6 \pm 1.9^{\mathrm{b}}$ & $59.4 \pm 1.3^{\mathrm{c}}$ \\
\hline a, b, c: Columns with different supperscript differ significantly $(\mathrm{P} \leq 0.05)$
\end{tabular}

a, b, c: Columns with different superscript differ significantly $(\mathrm{P} \leq 0.05)$

During the 2001/2002 breeding season, egg production was compromised with an increase in stocking rate in the 1 ha camps. Total egg production of the 141-bird flock declined $(\mathrm{P} \leq 0.01)$ by $21.3 \%$ and $20.2 \%$ compared to the 130-bird and 114-bird flocks, respectively. Chick production was similarly affected and declined by $21.2 \%$ and $22.0 \%$ when compared to the 130-bird and 114-bird flocks, respectively (Table 3). Average egg production declined $(\mathrm{P} \leq 0.01)$ by $0.441 \pm 0.007$ eggs per bird as flock size increased $\left(\mathrm{R}^{2}=0.94\right)$. Fertility and hatchability did not differ between the respective treatments $(P=0.13$ and $P=0.29)$. However, when the degrees of freedom were partitioned in orthogonal polynomials, a linear regression amounting to $-0.148 \pm 0.070 \%$ per breeding bird was observed for fertility $\left(\mathrm{P} \leq 0.05 ; \mathrm{R}^{2}=0.99\right)$. Hatchability similarly tended to decline $\left(-0.087 \pm 0.054 \%, \mathrm{P}=0.10 ; \mathrm{R}^{2}=0.99\right)$ with an increase in stocking rate.

Table 3 The influence of stocking rate on reproduction traits (means \pm s.e.) of ostriches maintained in 1 ha camps during the 2001/2002 breeding season

\begin{tabular}{lccc}
\hline & & Size of breeding flock \\
\cline { 2 - 4 } Parameter & 114 birds (38M:76F) & 130 birds (43M:87F) & 141 birds (47M:94F) \\
\hline Number of replicates & 8 & 4 & 8 \\
Total egg production & $2793 \pm 121^{\mathrm{a}}$ & $2834 \pm 171^{\mathrm{a}}$ & $2230 \pm 121^{\mathrm{b}}$ \\
Chicks (number) & $1937.9 \pm 86.8^{\mathrm{a}}$ & $1917.0 \pm 122.7^{\mathrm{a}}$ & $1510.1 \pm 86.8^{\mathrm{b}}$ \\
Average EP/female & $34.3 \pm 1.4^{\mathrm{a}}$ & $30.5 \pm 2.0^{\mathrm{a}}$ & $22.1 \pm 1.4^{\mathrm{b}}$ \\
Fertility (\%) & $83.6 \pm 1.3^{\mathrm{a}}$ & $81.2 \pm 1.9^{\mathrm{a}}$ & $79.6 \pm 1.3^{\mathrm{a}}$ \\
Hatchability (\%) & $78.4 \pm 1.0^{\mathrm{a}}$ & $77.3 \pm 1.5^{\mathrm{a}}$ & $76.0 \pm 1.0^{\mathrm{a}}$ \\
\hline
\end{tabular}

a, b, c: Columns with different superscripts differ significantly $(\mathrm{P} \leq 0.05)$

Under a constant male to female ratio of 1:2, fertility was improved by $9.5 \%$ for the 9-bird flocks maintained in the 0.13 ha camps, compared to the 9-bird flocks maintained in 0.30 ha camps (Table 4). A similar tendency was observed for hatchability, which was $6.0 \%$ higher for the 9-bird flocks maintained in the smaller 0.13 ha camps. Nine-bird flocks maintained in 0.13 ha camps produced on average 23.5 more chicks $(\mathrm{P} \leq 0.05)$ than the 9-bird flocks maintained in the larger 0.30 ha camps.

Average egg production per female was $68 \%$ higher $(\mathrm{P} \leq 0.01)$ for breeding trios, when compared to the 9-bird flocks (Table 5). However, fertility and hatchability of eggs produced by 9-birds flocks were significantly improved by $19.6 \%$ and $29.0 \%$, respectively (Table 5). When the average egg production per 
female is compared on a per trio basis, i.e. the 9-bird flock can be considered equivalent to two breeding trios, the 9-bird flocks produced on average $15.8 \%$ more eggs on a per trio basis than the breeding trios.

Table 4 Reproduction traits (means \pm s.e.) for 9-bird flocks maintained in 0.13 ha and 0.30 ha camps during the $2001 / 2002$ breeding season

\begin{tabular}{lcc}
\hline & \multicolumn{2}{c}{ Camp size } \\
\cline { 2 - 3 } Parameter & 0.13 ha & 0.30 ha \\
\hline Number of replicates & 50 & 50 \\
Total egg production & $255.6 \pm 10.8^{\mathrm{a}}$ & $233.4 \pm 10.8^{\mathrm{b}}$ \\
Average EP/female & $34.1 \pm 1.4^{\mathrm{a}}$ & $29.7 \pm 1.4^{\mathrm{b}}$ \\
Chicks (number) & $182.6 \pm 8.4^{\mathrm{a}}$ & $147.8 \pm 8 .^{\mathrm{b}}$ \\
Fertility (\%) & $81.6 \pm 1.4^{\mathrm{a}}$ & $74.5 \pm 1.4^{\mathrm{b}}$ \\
Hatchability (\%) & $75.1 \pm 1.0^{\mathrm{a}}$ & $70.6 \pm 1.0^{\mathrm{b}}$ \\
\hline \multicolumn{2}{c}{ a, b : Columns with different superscripts differ significantly $(\mathrm{P} \leq 0.05)$}
\end{tabular}

Table 5 The influence of stocking rate on the reproduction traits (means \pm s.e.) of ostriches maintained in 0.13 ha camps during the 2001/2002 breeding season

\begin{tabular}{lcc}
\hline & \multicolumn{2}{c}{ Flock size (M:F) } \\
\cline { 2 - 3 } Parameter & Trios (1M:2F) & 9-bird flock (3M:6F) \\
\hline Number of replicates & 83 & 50 \\
Total egg production & $114.7 \pm 5.8^{\mathrm{a}}$ & $255.6 \pm 7.4^{\mathrm{b}}$ \\
Average EP/female & $57.4 \pm 1.8^{\mathrm{a}}$ & $34.1 \pm 2.4^{\mathrm{b}}$ \\
Chicks (number) & $67.7 \pm 4.6^{\mathrm{a}}$ & $182.6 \pm 5.9^{\mathrm{b}}$ \\
Fertility (\%) & $68.2 \pm 1.2^{\mathrm{a}}$ & $81.6 \pm 1.7^{\mathrm{b}}$ \\
Hatchability (\%) & $58.2 \pm 1.3^{\mathrm{a}}$ & $75.1 \pm 1.6^{\mathrm{b}}$ \\
\hline \multicolumn{2}{c}{ a, b: Columns with different superscripts denote significance $(\mathrm{P} \leq 0.05)$}
\end{tabular}

As can be expected, total egg and chick production increased $(\mathrm{P} \leq 0.01)$ linearly with an increase in the number of females per breeding system (Table 6). Average egg production per female and fertility of eggs produced, however, did not differ between the different treatments. Hatchability was higher $(\mathrm{P} \leq 0.05)$ for eggs produced by the breeding quads (Table 6).

Table 6 The influence of male:female ratio on the reproduction traits (mean \pm s.e.) of ostriches maintained in 0.06 ha breeding camps during the 2000/2001 breeding season

\begin{tabular}{lccc}
\hline & \multicolumn{3}{c}{ Breeding system (M:F) } \\
\cline { 2 - 4 } Parameter & Pairs (1M:1F) & Trios (1M:2F) & Quads (1M:3F) \\
\hline Number of replicates & 50 & 125 & 8 \\
Total egg production & $25.9 \pm 2.3^{\mathrm{a}}$ & $52.1 \pm 1.4^{\mathrm{b}}$ & $92.6 \pm 5.7^{\mathrm{c}}$ \\
Average egg production & $21.6 \pm 1.1^{\mathrm{a}}$ & $21.7 \pm 0.7^{\mathrm{a}}$ & $25.8 \pm 2.7^{\mathrm{a}}$ \\
Chicks (number) & $21.9 \pm 2.0^{\mathrm{a}}$ & $42.6 \pm 1.3^{\mathrm{b}}$ & $80.5 \pm 5.0^{\mathrm{c}}$ \\
Fertility (\%) & $74.3 \pm 2.1^{\mathrm{a}}$ & $77.6 \pm 1.3^{\mathrm{a}}$ & $83.8 \pm 5.2^{\mathrm{a}}$ \\
Hatchability (\%) & $70.0 \pm 2.2^{\mathrm{a}}$ & $73.5 \pm 1.4^{\mathrm{a}}$ & $81.1 \pm 5.4^{\mathrm{b}}$ \\
\hline
\end{tabular}

a, b, c: Columns with different superscripts differ significantly $(\mathrm{P} \leq 0.05)$

Although maintained in slightly larger camps ( 0.30 vs. 0.35 ha) and at a higher stocking rate, the 13bird flocks performed on average better in terms of all reproduction traits compared to the 9-bird flocks (Table 7). Total egg production was increased $(\mathrm{P} \leq 0.01)$ for the 13-bird flocks. A similar tendency $(\mathrm{P} \leq$ $0.007)$ was observed for average egg production per female. Thirteen-bird flocks produced on average $233.72 \pm 8.56$ eggs in total and $21.65 \pm 0.90$ eggs/female, compared to $129.76 \pm 8.56$ eggs and $18.0 \pm 0.90$ 
eggs/female for the 9-bird flocks. Fertility and hatchability were also improved in the 13-bird flocks ( $\mathrm{P} \leq$ 0.01 and $\mathrm{P} \leq 0.008$, respectively, Table 7).

Table 7 Reproduction traits (means \pm s.e.) recorded for 9-bird and 13-bird flocks maintained in 0.30 and 0.35 ha camps, respectively, during the 2000/2001 breeding season

\begin{tabular}{lcc}
\hline & \multicolumn{2}{c}{ Flock size (M:F) } \\
\cline { 2 - 3 } Parameter & 9-bird flock (1M:2F) & 13-bird flock (1M:2.25F) \\
\hline Number of replicates & 25 & 25 \\
Total egg production & $129.8 \pm 8.6^{\mathrm{a}}$ & $233.7 \pm 8.6^{\mathrm{b}}$ \\
Chicks (number) & $108.0 \pm 7.4^{\mathrm{a}}$ & $198.3 \pm 7.4^{\mathrm{b}}$ \\
Average EP/female & $18.0 \pm 0.9^{\mathrm{a}}$ & $21.7 \pm 0.9^{\mathrm{b}}$ \\
Fertility (\%) & $84.9 \pm 1.3^{\mathrm{a}}$ & $90.3 \pm 1.3^{\mathrm{b}}$ \\
Hatchability (\%) & $79.4 \pm 1.4^{\mathrm{a}}$ & $86.1 \pm 1.4^{\mathrm{b}}$ \\
\hline
\end{tabular}

a, b: Columns with different superscripts differ significantly $(\mathrm{P} \leq 0.01)$

\section{Discussion \\ Large flocks:}

During the 2000/2001 breeding season, egg production was higher for the 210-bird/ha stocking rate, with egg production tending to increase linearly as the stocking rate was increased. This increase in egg production amounted to $11.9 \pm 5.4$ eggs per female, and accounted for $99.6 \%$ of the variation associated with treatments. The same tendency was observed for the number of chicks hatched, with an increase of $3.11 \pm 1.86$ chicks hatched per breeding bird. Fertility and hatchability, however, decreased significantly as stocking rate increased. The respective stocking rates did not influence average egg production. During the 2001/2002 breeding season, however, egg production was compromised when stocking rate was increased. Total egg production decreased in the 130-bird and 141-bird flocks, compared to the 114-bird flocks maintained in the 1 ha camps. Average egg production decreased by $0.44 \pm 0.007$ eggs per bird as stocking rate was increased. Fertility was lower and hatchability tended to decrease for the higher stocking rates.

The contradictory results obtained during the two breeding seasons can be explained by the translocation of a proportion of the breeding population to a new breeding environment two months before the onset of breeding during the 2000/2001 breeding season. These newly imported birds were allocated to a number of the 210-bird flocks. These breeding birds might not have had sufficient time to adapt to their new environment. Translocation to a new and unfamiliar environment results in disorientation and the consequent manifestation of abnormal behavioural patterns (Lambrechts et al., 1998). Results from this study suggest that the respective flocks were still acclimatizing to the new breeding environment that differed in terms of vegetation, climate and management. With the onset of breeding during the 2001/2002 breeding season the imported birds had sufficient time to acclimatize and this was reflected in the production figures of the flock at the lower 114 birds/ha stocking rates.

The tendency for fertility and hatchability to be negatively influenced in the larger flocks during both breeding years supports the reasoning that too high a stocking rate adversely affects the reproductive performance of ostriches. It is possible that corticosterone levels were higher in females maintained at the higher stocking rates than at lower stocking rates, and this might have had a negative influence on ovulation and subsequent oviposition. Corticosterone levels were found to be higher in laying hens housed at higher than at lower densities (Mashaly et al., 1984). Abnormal doses of corticosteroids resulted in premature LH release and irregular laying patterns in laying hens (Gilbert, 1971). The high stocking densities also may have had a negative influence on the normal reproductive behaviour of the ostrich males, i.e. overtly aggressive ostrich males might have prevented other less dominant males from mating successfully with females. Courtship and mating behaviour of ostriches have been well-documented (Bolwig, 1973; Stewart, 1994; Berendsen, 1995; Hicks-Aldredge, 1996; Deeming, 1997; Bubier et al., 1998). Any change in the immediate environment could disrupt normal reproductive behaviour (Lambrechts et al., 1998b). The borders of male territories seldom overlap (Sauer \& Sauer, 1966; McKeegan \& Deeming, 1997) and the high stocking rates possibly prevented males from establishing clear territories, resulting in the males spending relatively more time on aggressive interactions with other males and less time on territorial defence and reproductive interaction with females. The increase in fighting bouts between males also possibly disturbed 
the laying activity of females in these flocks. Wechsler \& Schmid (1998) found that aggressive interactions were significantly increased in multiple-male groups of Japanese quail (Coturnix japonica). The abnormal behaviour patterns observed at the higher stocking rates agree with findings in poultry where high stocking rates had a negative influence on the reproduction performance and well-being of laying hens (Hughes \& Wood-Gush, 1977; Blokhuis \& Wiepkema, 1998; Sherwin \& Kelland, 1998; Martrenchar et al., 1999; Savory et al., 1999; Bilcik \& Keeling, 2000; Klein et al., 2000). The high stocking rates of 150 birds, 141 birds and 210 birds/ha also contributed to an increased incidence of homosexual behaviour and feather pecking, both during the breeding and the non-breeding periods.

\section{Small flocks:}

In contrast to the influence of too high a stocking rate on the production of the large flocks, the 9-bird flocks maintained in the smaller 0.13 ha camps outperformed the 9-bird flocks in the larger 0.30 ha camps in terms of almost all production parameters. Total eggs produced tended to be improved, and average egg production per female was improved for 9-bird flocks maintained in the smaller 0.13 ha camps. Fertility, hatchability, and consequent chick production of the 9-bird flocks in the 0.13 ha camps was similarly improved. A possible explanation for this improvement in the respective production traits is the increased frequency of encounters between males and females in the smaller camps than in the larger 0.3 ha camps. The smaller camp size of 0.13 ha did not appear to influence reproductive behaviour of the birds. It would appear that the establishment of clear territories was not inhibited during the study period. The smaller 0.13 ha camps might actually have contributed to females visiting different territories more frequently than in the larger 0.30 ha camps, and this possibly resulted in a higher frequency of sexual encounters, which in turn could have contributed to the higher production performance of the 9-bird flocks in the smaller 0.13 ha camps than in the larger camps.

When the production of breeding trios and 9-bird flocks in 0.13 ha camps is considered, the 9-bird flocks performed on average better for all reproduction traits with the exception of average egg production per female. The improvement in almost all the reproduction traits in the 9-bird flocks can be ascribed to the higher number of females and males present in this breeding system when compared to the trios. Average egg production, however, was compromised for the higher stocking density of nine birds per 0.13 ha. The improved fertility and hatchability for the 9-bird flocks maintained in 0.13 ha camps can be ascribed to the stimulating effect of more than one male in this breeding system. Females had the opportunity to visit more than one male's territory and this possibly contributed to more frequent sexual encounters and the higher fertility and hatchability recorded for the 9-bird flocks.

When production of the smaller 9-bird and 13-bird flocks is compared, the 13-bird flocks performed significantly better than the 9-bird flocks in terms of all reproduction traits, i.e. total egg production, average egg production per female, number of chicks hatched, fertility and hatchability. When the two breeding systems are compared on an area/bird basis, it becomes evident that reproductive performance is not only stocking rate dependent. The higher density in the 0.35 ha camps $\left(269.2 \mathrm{~m}^{2} / \mathrm{bird} v \mathrm{~s} .333 .3 \mathrm{~m}^{2} / \mathrm{bird}\right)$, possibly had the effect that sexual encounters between the males and females were more frequent, which in turn contributed to the improved fertility and hatchability. It is difficult; however, to reach a conclusion with regard to the improved production of the 13-bird flocks, for the slight increase in camp size might also have had a positive influence on the production performance of the 13-bird flocks.

Increasing the number of females per male in the 0.06 ha camps had the effect that egg production increased linearly with $29.1 \pm 2.3$ eggs per camp, with a corresponding linear increase of $24.2 \pm 2.0$ chicks per camp. Average egg production per female, however, was not similarly affected. Fertility and hatchability were significantly improved for the breeding quads. An important observation was that neither fertility nor hatchability was compromised when the number of females was increased. A possible explanation for this is that the breeding quads are similar to a breeding harem that is usually established by males during a breeding season. Ostriches are gregarious by nature and the stimulus of an increase in the number of individuals in the respective breeding systems is reflected in the improvement in almost all the reproduction traits of the breeding quads in the study. Deeming (1996) found that breeding pairs and trios were more productive than larger flocks. Results obtained in this study support the findings of Deeming. His study, however, did not include a comparison of breeding quads with the larger flocks. Based on the results in the study it can be assumed that breeding quads will be more productive on a per female basis than larger flocks. However, it has to be conceded that the number of replicates studied for the breeding quads was relatively small when compared to other studies (Craig et al., 1977; Bates et al., 1987; Deeming \& Wadland, 2001; Campo \& 
Davilla, 2002). It is therefore possible that the breeding quads could have performed exceptionally well under these circumstances.

Our results are contradictory to results reported by More (1997) who found that the laying performance of breeding pairs tended to be better than that of both trios and a breeding flocks. However, although female age influenced egg production significantly, no mention was made of the composition of the respective breeding systems. The improvement in the fertility and hatchability for the breeding quads is contradictory to the decline in fertility reported when the number of females was increased in single-male groups of Japanese quail (Coturnix japonica) and commercial pheasants (Phasianus colchinus) (Bates et al., 1987; Wechsler \& Schmid, 1998; Deeming \& Wadland, 2002). Single-male groups containing 8, 12, 16 and 20 hens and had fertility percentages of 92\%, 84\%, 77\% and 69\%, respectively (Wechsler \& Schmid, 1998). Increasing the number of females from $1 \mathrm{M}: 12 \mathrm{~F}$ to $1 \mathrm{M}: 18 \mathrm{~F}$ in pheasants increased egg production with a subsequent decrease in fertility. Campo \& Davilla (2002) investigated the influence of four different mating ratios on stress and fearfulness indicators in chickens. Their results suggested that too high mating ratios increased physiological and psychological stress responses. Deeming \& Wadland (2002) investigated the effect of two mating ratios, i.e. $1 \mathrm{M}: 8 \mathrm{~F}$ and $1 \mathrm{M}: 12 \mathrm{~F}$, in commercial pheasant flocks. Flocks with a mating ratio of $1 \mathrm{M}: 8 \mathrm{~F}$ produced significantly more eggs, and fertility and hatchability were improved significantly. The higher M:F ratio of the breeding quads therefore indicates that ostrich males can successfully keep and service a harem consisting of at least three females. Higher M:F ratios, however, were not investigated in our study. In the wild, the harem of an ostrich male usually consists of 3-5 females (Deeming \& Bubier, 1999).

Factors such as age and subspecies might also influence the reproductive performance of ostriches under intensive breeding conditions. These details were not available for the breeding population, given the commercial nature of the farming operation. The breeding birds were acquired from sources that kept no records of either the origin or age of the breeding birds. The breeding population also consisted of ostriches that originated mostly from Zimbabwe and throughout South Africa, but no record was kept on the exact origin and the extent of in- and crossbreeding. It is therefore possible that an unbalanced composition of some of the breeding systems could have contributed to the variation observed in this study. The results also represent the production of a single commercial operation in the Little Karoo region of South Africa. This must be kept in mind when considering the results, because the production performance of ostriches under intensive commercial conditions may be influenced by location, age, subspecies and/or management.

\section{Conclusion}

Results indicated that a "trade-off" in performance was observed for different aspects of reproduction, i.e. when average egg production per female was improved, fertility and hatchability were compromised. The 114-breeding flocks performed the best in 1 ha $\left(10000 \mathrm{~m}^{2}\right)$ breeding camps, in terms of all the reproduction traits. Increasing the stocking rate in smaller 0.13 ha $\left(1250 \mathrm{~m}^{2}\right)$ breeding camps had the effect that although average egg production/female was lower, fertility and hatchability were improved, possibly as a result of more frequent sexual interactions of males and females. Breeding pairs, trios and quads could be maintained with acceptable production levels on smaller areas than are normally prescribed. Although the number of quads in the study was relatively small, it indicates that harem size under intensive conditions may be as high as three females per male, which supports the polygamous nature of ostrich males.

Our findings indicate that breeding ostriches could be maintained at stocking rates higher than what is currently recommended for intensive commercial ostrich breeding enterprises. This has important implications in terms of the intensification of ostrich farming, especially in areas that are characterised by vegetation that is exposed to the trampling effect of ostriches. However, too high stocking rates may have a negative influence on normal reproductive behaviour, and thereby may not be beneficial for reproduction as well as the well-being of ostriches under intensive farming conditions.

\section{References}

Adams, J. \& Revell, B.J., 2003. Ostrich farming - a review and feasibility study of opportunities in the EU. Available at: http:॥www.mluri.sari.ac.uk।

Animal Welfare Advisory Committee, 1998. Code of Recommendations and minimum standards for the welfare of ostrich and emu. Code of Animal Welfare No. 21, ISBN 0-478-07476-X, Ministry of Agriculture and Forestry, PO Box 2526, Wellington, New Zealand. 
Bates, D.P., Hanson, L.E., Cook, M.E., Wentworth, B.C., Sunde, M.L. \& Bitgood, J.J., 1987. Lighting and sex ratio for breeding ringnecked pheasants in confined housing. Poult. Sci. 66, 605-612.

Berendsen, K.D., 1995. Behaviour. In: Ostrich Farm Management. Eds. Kreibich, A. \& Sommer, M., Landwirtschaftsverlag GmbH, Münster-Hiltrup, Germany. pp. 25-32.

Bilcik, B. \& Keeling, L.J., 2000. Relationship between feather pecking and ground pecking in laying hens and the effect of group size. Appl. Anim. Behav. Sci. 68, 55-66.

Blokhuis, H.J. \& Wiepkema, P.R., 1998. Studies of feather pecking in poultry. Vet. Quat. 20, 6-9.

Bolwig, N., 1973. Agonistic and sexual behaviour of the African ostrich (Struthio camelus). Condor 5, 100105.

Bubier, N.E., Paxton, C.G.M., Bowers, P. \& Deeming, D.C., 1998. Courtship behaviour of farmed ostriches in relation to humans. Br. Poult. Sci. 39, 477-481.

Bunter, K.L. \& Graser, H-U., 2000. Genetic evaluation for Australian ostriches - a report for the Rural Industries Research and Development Corporation. Publication no. 00/153, Rural Industries Research and Development Corporation, Australia.

Campo, J.L. \& Davilla, S.G., 2002. Influence of mating ratio and group size on indicators of fearfulness and stress of hens and cocks. Poult. Sci. 81, 1099-1103.

Craig, J.V., Al-Rawi, B. \& Kratzer, D.D., 1977. Social status and sex ratio effects on mating frequency of cockerels. Poult. Sci. 56, 767-772.

Deeming, D.C., 1996. Production, fertility and hatchability of ostrich (Struthio camelus) eggs on a farm in the United Kingdom. Anim. Sci. 67, 329-336.

Deeming, D.C., 1997. Ratite egg incubation - a practical guide. Ratite Conf, Buckinghamshire, United Kingdom.

Deeming, D.C. \& Bubier, N.E., 1999. Behaviour in natural and captive environments. In: The Ostrich: Biology, production and health. Ed. Deeming, D.C., CABI Publishing, CAB International, Wallingford, Oxon, United Kingdom. pp. 83-104.

Deeming, D.C. \& Wadland, D., 2001. Observations on the patterns of embryonic mortality over the laying season of pheasants. Br. Poult. Sci. 42, 569-573.

Deeming, D.C. \& Wadland, D., 2002. Influence of mating sex ration in commercial pheasant colonies on bird health and the production, fertility and hatchability of eggs. Br. Poult. Sci. 43, 16-23.

Foggin, C.M. \& Van Niekerk, A., 1995. Ostriches in the wild, colony breeding and foster rearing. Proc. $5^{\text {th }}$ Aust. Ostrich Assoc. Conf. pp. 111-116.

Gilbert, A.B., 1971. Control of ovulation. In: Physiology and Biochemistry of the Fowl, volume 3, Eds. Bell D.J. \& Freeman, B.M., Academic Press, London. pp. 1225-1235.

Harvey, W.R., 1990. User’s guide for LSMLMW and MIXMDL. PC-2 version, Mimeograph.

Hicks-Aldredge, K.D., 1996. Reproduction. In: Ratite management, medicine and health. Eds. Tully, T.N. \& Shane, S.M., Krieger Publishing Co., Malabar, Florida. pp. 47-57.

Horbañczuk, J.O., 2002. The history and current status of ostrich farming in Poland. Proc. World Ostrich Congr., 26-29 September, Warsaw, Poland. pp. 7-13.

Hughes, B.O. \& Wood-Gush, D.G., 1977. Agonistic behaviour in domestic hens: the influence of housing method and group size. Anim. Behav. 25, 1056-1062.

Hurxthal, L.M., 1979. Breeding behaviour of the ostrich Struthio camelus massaicus Neumann on the Nairobi National Park. PhD thesis, University of Nairobi, Kenya.

Jarvis, M.J.F., Jarvis, C. \& Keffen, R.H., 1985. Breeding seasons and laying patterns of the southern African ostrich Struthio camelus. Ibis 127, 442-449.

Klein, T., Zeltner, E. \& Huber-Eicher, B., 2000. Are genetic differences in foraging behaviour of laying hens chicks paralleled by hybrid-specific differences in feather pecking? Appl. Anim. Behav. Sci. 70, 143-155.

Lambrechts, H., Cloete, S.W.P, Swart, D., Van Schalkwyk, S.J. \& Greyling, J.P.C., 2002. Egg production and fertility of ostriches as influenced by stocking density and male:female ratio. Proc. $1^{\text {st }}$ Joint Congr. Grassland Soc. S. Afr. and S. Afr. Soc. Anim. Sci., 13-16 May 2002, Christiana Aventura, South Africa. p. 103.

Lambrechts, H., Huchzermeyer, F.W. \& Swart, D., 1998. Integrating ostrich behaviour in commercial farming systems. Proc. ${ }^{\text {nd }}$ Int. Ratite Scientific. Congr. 21-25 September, Oudtshoorn, South Africa. pp. 167-169. 
Martrenchar, A., Huonnic, D., Cotte, J.P., Boilletot, E. \& Morisse, J.P., 1999. Influence of stocking density on behavioural, health and productivity traits of turkeys in large colonies. Br. Poult. Sci. 40, 323-331.

Mashaly, M.M., Webb, M.L., Youtz, S.L., Roush, W.B. \& Graves, H.B., 1984. Changes in serum corticosterone concentration of laying hens as a response to increased population density. Poult. Sci. 63, 2271-2274.

McKeegan, D.E.F. \& Deeming, D.C., 1997. Effects of gender and group size on the time-activity budgets of adult breeding ostriches (Struthio camelus) in a farming environment. Appl. Anim. Behav. Sci. 51, 159-177.

More, S.J., 1997. Monitoring the health and productivity of farmed ostrich colonies. Aust. Vet. J. 75, 583587.

Sauer, E.G.F. \& Sauer, E.M., 1966. The behaviour and ecology of the South African ostrich. Living Bird 5, 45-75.

Savory, C.J., Mann, J.S. \& MacLeod, M.G., 1999. Incidence of pecking damage in growing bantams in relation to food form, group size, stocking density, dietary tryptophan concentration and dietary protein source. Br. Poult. Sci. 40, 579-584.

Sherwin, C.M. \& Kelland, A., 1998. Time-budgets, comfort behaviours and injurious pecking of turkeys housed in pairs. Br. Poult. Sci. 39, 325-332.

Smith, W.A., Cilliers, S.C., Mellett, F.D. \& Van Schalkwyk, S.J., 1995. Ostrich Production - a South African perspective. In: Biotechnology in the Feed Industry - Proc. Alltech's $11^{\text {th }}$ Ann. Symp, Ed. Lyons, T. \& Jacques, K.A., Nottingham University Press. pp. 175-197.

Snedecor, G.W. \& Cochran, W.G., 1967. Statistical methods, $6^{\text {th }}$ edition. Iowa State University, U.S.A.

South African Ostrich Business Chamber, 2003. Riglyne vir die benutting van natuurlike veld deur volstruisboerdery: 'n gedragskode vir volstruisprodusente. South African Ostrich Business Chamber, PO Box 952, Oudtshoorn, South Africa.

Stewart, J.S., 1994. Ostrich behaviour and behavioural problems. Assoc. Avian Vet. Proc. 103-109.

Van Zyl, P.L., 2001. 'n Ekonomiese evaluering van volstruisboerdery in die Oudtshoorn omgewing. MSc thesis, University of Stellenbosch, South Africa.

Wechsler, B. \& Schmid, I., 1998. Aggressive pecking by males in breeding groups of Japanese quail (Coturnix japonica). Br. Poult. Sci. 39, 333-339. 